\title{
Świadomość pacjentów na temat późnych powikłań cukrzycy typu 2
}

\author{
Patients' awareness of late complications \\ in type 2 diabetes
}

\author{
ANNA ANTCZAK-KOMOTERSKA ${ }^{1}$, BEATA BORUCZKOWSKA ${ }^{2}$ \\ ${ }^{1}$ Państwowa Uczelnia Zawodowa we Włocławku, Instytut Nauk o Zdrowiu \\ ${ }^{2}$ Centrum Diagnostyczno-Lecznicze Barska we Włocławku
}

DOI: http://dx.doi.org/10.21784/IwP.2020.022

ISSN: 2451-1846

\section{Streszczenie}

Wstęp. Cukrzyca to grupa chorób metabolicznych charakteryzująca się hiperglikemią wynikającą z defektu produkcji lub działania insuliny wydzielanej przez komórki beta trzustki. Najczęstszą postacią cukrzycy jest cukrzyca typu 2, w której pierwotnie dochodzi do zmniejszonej wrażliwości tkanek na insulinę (insulino oporność). Wieloletnia cukrzyca prowadzi do wielu groźnych powikłań, które dotyczą wielu narządów, np. narządu wzroku, nerek czy włókien nerwowych.

Cel. Celem pracy była ocenia świadomości pacjentów na temat późnych powikłań cukrzycy typu 2.

Materiał i metody. W badaniu wzięło udział 100 pacjentów zarówno płci żeńskiej jak i męskiej leczących się w Poradni Diabetologicznej CDL Barska. Wybrano metodę sondażu diagnostycznego, zastosowano technikę ankietową i analizę dokumentacji medycznej. Narzędziem badawczym wykorzystanym w pracy był autorski kwestionariusz ankiety oraz dokumentacja medyczna.

Wyniki. Z przeprowadzonych badań własnych wynika, że zdecydowaną większość pacjentów stanowią kobiety (63\%), powyżej 60 roku życia (40\%), mieszkające w mieście (62\%), aktywne zawodowo (44\%), które chorowały poniżej 5 lat (45\%). Najwięcej badanych wskazywało na uczestniczenie 
w konsultacjach okulistycznych (65\%). Największa grupa badanych wskazywała na powikłanie w postaci nadciśnienia $(37,4 \%)$, zaburzenie widzenia $(23,7 \%)$, najmniej wskazało na stopę cukrzycową $(0,7 \%)$.

Słowa kluczowe: cukrzyca; powikłania cukrzycy; retinopatia; neuropatia; nefropatia; kardiomiopatia; stopa cukrzycowa.

\begin{abstract}
Admission. Diabetes mellitus is a group of metabolic diseases characterized by hyperglycaemia resulting from a defect in the production or function of insulin secreted by the beta cells of the pancreas. The most common form of diabetes is type 2 diabetes, in which there is primarily a decreased sensitivity of tissues to insulin (insulin resistance). Long-term diabetes leads to many serious complications that affect many organs, such as the eyes, kidneys and nerve fibers.
\end{abstract}

Aim. The aim of the study was to assess the patients' awareness of late complication of type 2 diabetes.

Material and methods. The study involved 100 female and male patients treated at the CDL Barska Diabetes Clinic. The diagnostic survey method was selected, the survey technique and the analysis of medical records were used. The research tool used in the work was the original questionnaire and medical documentation.

Results. The conducted research shows that the vast majority of patients are women (63\%), over $60(40 \%)$, living in the city (62\%), professionally active (44\%), who were ill for less than 5 years (45\%) . Most respondents indicated participation in ophthalmological consultations (65\%). The largest group of respondents indicated a complication in the form of hypertension $(37.4 \%)$, visual impairment (23.7\%), and the least indicated a diabetic foot $(0.7 \%)$.

Keywords: diabetes; diabetes complications; retinopathy; neuropathy; nephropathy; cardiomyopathy; diabetic foot. 


\section{Wstęp}

Według WHO cukrzyca: „Jest to grupa chorób metabolicznych charakteryzująca się hiperglikemią wynikającą z defektu wydzielania i/lub działania insuliny. Przewlekła hiperglikemia w cukrzycy wiąże się z uszkodzeniem, zaburzeniem czynności i niewydolnością różnych narządów, szczególnie oczu, nerek, nerwów, serca i naczyń krwionośnych" [1].

Objawem cukrzycy jest podwyższone stężenie glukozy we krwi, a także opornością na działanie insuliny, mimo tego, że jej stężenie we krwi jest prawidłowe. Stan ten nazywany jest insulinoopornością znaczne obniżenie wrażliwości tkanek organizmu na działanie insuliny[2].

Cukrzyca typu 2 to choroba, która stanowi ogromny problem epidemiologiczny i diabetologiczny. Jest jednym z bardzo ważnych i trudnych zagadnień w medycynie XXI wieku [5]. Cukrzyca typu 2 jest jedną z głównych przyczyn przedwczesnej umieralności głównie z powodu sercowo-naczyniowe. Niesie za sobą również groźne powikła prowadzących do ślepoty, amputacji kończyn oraz niewydolności nerek. Przy rozpoznaniu cukrzycy typu 2 oczekiwana długość życia znacząco się skraca[6,7].

Do późnych powikłań cukrzycy zaliczamy :

- Retinopatia cukrzycowa - to zespół zmian czynnościowych, biochemicznych i anatomicznych wstępujących w przebiegu cukrzycy. Zmiany te prowadzą do zaburzeń widzenia, niekiedy do całkowitej utraty wzroku. Mogą zostać uszkodzone wszystkie struktury oka. Są to zmiany o podłożu naczyniowym. Retinopatia cukrzycowa często przebiega bez objawów - nie pojawiają się ani problemy z widzeniem, ani dolegliwości bólowe. Dlatego bardzo ważne są badania przesiewowe u pacjenta chorującego na cukrzycę[1,8,9]. 
- Nefropatia cukrzycowa -charakteryzuje się nieodwracalnym i postępującym pogorszeniem czynności nerek. Dochodzi do uszkodzenia włośniczek kłębuszka nerkowego, które wynika z długotrwałego zwiększonego stężenia glukozy we krwi i innych zmian patologicznych u chorych na cukrzycę - makroangiopatia cukrzycowa (choroba wieńcowa, miażdżyca naczyń obwodowych) $[1,8,9]$.

- Neuropatia cukrzycowa- uszkodzenie nerwów. Główną przyczyną neuropatii cukrzycowej jest hiperglikemia, która powoduje zaburzenia budowy włókien nerwowych oraz zaburzenia ich funkcji, polegającej na przewodzeniu impulsów nerwowych. jest przyczyną silnych dolegliwości powodujących pogorszenie jakości życia i jest znaczącym czynnikiem ryzyka rozwoju stopy cukrzycowej oraz nagłego zgonu[1,8,9].

- Kardiomiopatia cukrzycowa -postępująca choroba mięśnia sercowego prowadząca do zaburzeń jego budowy i czynności skutkująca osłabieniem czynności skurczowej i niewydolnością serca. W efekcie organizm pozbawiony jest utlenowanej krwi co może doprowadzić do zgonu. Cukrzyca doprowadza w obrębie mięśnia sercowego do mikroangiopatii $[1,8,9]$.

- Stopa cukrzycowa - występowanie infekcji, owrzodzenia i/lub destrukcję tkanek głębokich w obrębie kończyn dolnych poniżej kostki u pacjentów z cukrzycą, u których stwierdzono neuropatięi/lub zmiany miażdżycowe kończyn dolnych. W rozwoju zespołu stopy cukrzycowej najważniejszą rolę odgrywa neuropatia cukrzycowa i miażdżyca tętnic kończyn dolnych. Hiperglikemia jest głównym czynnikiem, który powoduje uszkodzenie nerwów, jak też nasilenie i przyspieszenie miażdżycy tętnic kończyn dolnych. Oprócz hiperglikemii rozwojowi miażdżycy sprzyjają również czynniki takie jak zaburzenia lipidowe, insulinooporność, dysfunkcja śródbłonka, owrzodzenia[1,8,9]. 


\section{Cel}

Celem niniejszej pracy była ocenia świadomości pacjentów na temat późnych powikłań cukrzycy typu 2.

\section{Materiał i metody}

W badaniu wzięło udział 100 pacjentów zarówno płci żeńskiej jak i męskiej leczących się w Poradni Diabetologicznej CDL Barska. Wybrano metodę sondażu diagnostycznego, zastosowano technikę ankietową i analizę dokumentacji medycznej. Narzędziem badawczym wykorzystanym w pracy był autorski kwestionariusz ankiety oraz dokumentacja medyczna.

\section{Wyniki}

Tabela I. Zauważone objawy.

\begin{tabular}{|l|r|r|}
\hline Objawy & \multicolumn{1}{|c|}{ Liczba } & \multicolumn{1}{|c|}{$\%$} \\
\hline bóle nóg & 2 & 3,9 \\
\hline choroba wieńcowa & 1 & 2,0 \\
\hline miażdżyca kończyn dolnych & 3 & 5,9 \\
\hline nadciśnienie & 20 & 39,2 \\
\hline stenty & 2 & 3,9 \\
\hline stopa cukrzycowa & 1 & 2,0 \\
\hline zaburzenia pracy serca & 3 & 5,9 \\
\hline zaburzenia widzenia & 6 & 11,8 \\
\hline zaburzenie pracy serca & 1 & 2,0 \\
\hline zaburzenie siatkówki & 1 & 2,0 \\
\hline zawal bypassy & 1 & 2,0 \\
\hline zawal serca & 9 & 17,6 \\
\hline złe bicie serca & 1 & 2,0 \\
\hline Razem & 51 & 100,0 \\
\hline
\end{tabular}


Wskazując na zauważone objawy badani wymieniali po kilka stwierdzeń. Łącznie od 41 osób odnotowano 51 odpowiedzi. Najwięcej badanych wskazało na nadciśnienie - 20 osób, co stanowiło 39,2\%) wszystkich wymienionych stwierdzeń. Dalej wskazywali na zawał serca - 9 osób $(17,6 \%)$ oraz zaburzenia widzenia - 6 osób (11,8\%)

Tabela II. Wystąpienie powikłań.

\begin{tabular}{|l|l|l|}
\hline powikłania & liczba & $\%$ \\
\hline zaburzenia widzenia & 33 & 23,7 \\
\hline $\begin{array}{l}\text { bóle kończyn dol- } \\
\text { nych }\end{array}$ & 23 & 16,5 \\
\hline $\begin{array}{l}\text { zaburzenia pracy } \\
\text { serca }\end{array}$ & 30 & 21,6 \\
\hline nadciśnienie tętnicze & 52 & 37,4 \\
\hline stopa cukrzycowa & 1 & 0,7 \\
\hline Razem & 139 & 100,0 \\
\hline
\end{tabular}

Odpowiadając na pytanie o wystąpienie powikłań badani zaznaczali po kilka twierdzeń. Łącznie odnotowano 139 odpowiedzi. Najwięcej wskazało na nadciśnienie tętnicze - 52 osoby, co stanowiło 37,4\% wszystkich odpowiedzi. Dalej wskazywali na zaburzenia widzenia - 33 osoby $(23,7 \%)$. Najmniej wskazało na stopę cukrzycową - 1 osoba $(0,7 \%)$. Na jedno powikłanie wskazało - 49 osób, dwóch powikłań 27 osób, trzech powikłań - 8 osób i czterech powikłań - 3 osoby. 
Tabela III. Sposób prowadzenia samokontroli oznak cukrzycy.

\begin{tabular}{|l|r|r|}
\hline Odpowiedź & \multicolumn{1}{|c|}{ Liczba } & \multicolumn{1}{c|}{$\%$} \\
\hline $\begin{array}{l}\text { badam stężenie glukozy } \\
\text { przy użyciu gleukometru }\end{array}$ & 96 & 54,9 \\
\hline kontroluję ciśnienie & 41 & 23,4 \\
\hline kontroluję masę ciała & 28 & 16,0 \\
\hline kontroluję wygląd stóp & 9 & 5,1 \\
\hline inne & 175 & 100,0 \\
\hline Razem & & 0,6 \\
\hline
\end{tabular}

Wskazując na sposoby prowadzenia oznak samokontroli cukrzycy badani zaznaczali po kilka stwierdzeń. Łącznie odnotowano 175 odpowiedzi. Najwięcej wskazało badam stężenie glukozy przy użyciu gleukometru - 96 osób, co stanowiło 54,9\% wszystkich odpowiedzi oraz na kontrolę ciśnienia - 41 osób $(23,4 \%)$. Najmniej wskazało na inne sposoby - 1 osoba $(0,6 \%)$. Na jeden sposób wskazało - 50 osób, na dwa sposoby - 32 osoby, na trzy sposoby - 11 osób i na cztery sposoby 7 osób. 
Tabela IV. Częstość sprawdzania poziomu glukozy.

\begin{tabular}{|l|r|r|}
\hline Odpowiedź & \multicolumn{1}{|c|}{ Liczba } & \multicolumn{1}{c|}{$\%$} \\
\hline raz w tygodniu & 9 & 9,0 \\
\hline dwa razy w tygodniu & 40 & 40,0 \\
\hline $\begin{array}{l}\text { dwa razy w tygodniu } \\
\text { cztery razy dziennie }\end{array}$ & 29 & 29,0 \\
\hline raz na dwa tygodnie & 6 & 6,0 \\
\hline $\begin{array}{l}\text { raz na dwa tygodnie } \\
\text { cztery razy dziennie }\end{array}$ & 9 & 9,0 \\
\hline rzadziej & 100 & 100,0 \\
\hline Razem & 7,0 \\
\hline
\end{tabular}

Najwięcej badanych stwierdziło, że poziom glukozy sprawdza dwa razy w tygodniu - 40,0\% lub dwa razy w tygodniu cztery razy dziennie - 29,0\%, najmniej wskazało, że raz na dwa tygodnie - 6,0\%.

Tabela V. Sposoby pielęgnacji stóp.

\begin{tabular}{|l|r|r|}
\hline Odpowiedź & \multicolumn{1}{|c|}{ Liczba } & \multicolumn{1}{|c|}{$\%$} \\
\hline $\begin{array}{l}\text { myję w gorącej wodzie i osuszam poprzez ener- } \\
\text { giczne wycieranie szorstkim ręcznikiem }\end{array}$ & 8 & 7,2 \\
\hline $\begin{array}{l}\text { myję w letniej wodzie i delikatni osuszam kładąc } \\
\text { nacisk na przestrzenie między palcami }\end{array}$ & 85 & 76,6 \\
\hline usuwam samodzielnie odciski/modzele & 13 & 4,5 \\
\hline dwa razy dziennie nawilżam stopy kremem do stóp & 111 & 100,0 \\
\hline Razem &
\end{tabular}


Wskazując na sposoby pielęgnacji stóp badani zaznaczali po kilka stwierdzeń. Łącznie odnotowano 111 odpowiedzi. Najwięcej wskazało myję w letniej wodzie i delikatni osuszam kładąc nacisk na przestrzenie między palcami - 85 osób, co stanowiło 76,6\% wszystkich odpowiedzi oraz dwa razy dziennie nawilżam stopy kremem do stóp - 13 osób $(11,7 \%)$. Najmniej wskazało na usuwam samodzielnie odciski/ modzele - 5 osób (4,5\%). Na jeden sposób wskazało - 89 osób, na dwa sposoby - 11 osób.

Tabela VI. Korelacje wykształcenia i wyników zagadnień samokontroli w cukrzycy.

\begin{tabular}{|c|c|c|c|c|}
\hline Pozycja & $\mathbf{N}$ & $\mathbf{R}$ & $t(N-2)$ & $\begin{array}{c}\text { poziom } \\
\text { p }\end{array}$ \\
\hline $\begin{array}{l}\text { jak prowadzi Pan/i samokontrolę } \\
\text { oznak cukrzycy }\end{array}$ & 100 & 0,065 & 0,644 & 0,521 \\
\hline $\begin{array}{l}\text { częstość sprawdzania poziomu glu- } \\
\text { kozy }\end{array}$ & 100 & 0,201 & 2,034 & 0,045 \\
\hline sposoby pielęgnacji stóp & 100 & 0,153 & 1,586 & 0,051 \\
\hline
\end{tabular}

Wykształcenie badanych, pozostawało w istotnej statystycznie korelacji z wynikami zagadnienia częstość sprawdzania poziomu glukozy $(\mathrm{p}<0,05)$.

\section{Dyskusja}

W cukrzycy ważne jest poznanie wiedzy pacjentów na temat tej choroby, jej objawów oraz konsekwencji z nią związanych. Ponad 90\% pacjentów z cukrzycą stwierdza, że edukacja jest bardzo ważna w leczeniu cukrzycy. Ważną częścią opieką nad chorym winno być mobilizowanie do samodzielnego prowadzenia samokontroli [10].

Najwięcej badanych wskazywało na uczestniczenie w konsultacjach okulistycznych (65\%). Największa grupa badanych wskazywała 
na powikłanie w postaci nadciśnienia $(37,4 \%)$, zaburzenie widzenia $(23,7 \%)$, najmniej wskazało na stopę cukrzycową $(0,7 \%)$. Najwięcej osób odpowiedziało, że do diabetologa uczęszcza 2 razy w roku (43\%). Pacjenci podają, że edukacja chorych na cukrzycę jest ważna (95\%). U większości nikt w rodzinie nie chorował (58\%), a zdecydowana większość uważa, iż wczesne wykrycie cukrzycy typu 2 jest ważne (97\%).

Wiedza na temat samokontroli pacjentów chorych na cukrzycę jest kluczem do osiągnięcia sukcesów w tej chorobie. Z przeprowadzonych badań własnych wynika, że najwięcej badanych posiadało wykształcenie średnie (32\%), osoby te chorowały poniżej 5 lat (45\%). Wskazując na sposoby prowadzenia oznak samokontroli cukrzycy badani najczęściej wskazywali na badanie stężenia glukozy przy użyciu glukometru $(54,9 \%)$ oraz kontrolę ciśnienia $(23,4 \%)$. Najwięcej badanych stwierdziło, że poziom glukozy sprawdza dwa razy w tygodniu $(40,0 \%)$.

Według Kołpy, Grochowskiej, Kubik i Stradomskiej badani po rozpoznaniu cukrzycy deklarowali zmianę stylu życia obejmującą samokontrolę (86,5\%), regularne wizyty u diabetologa (76,3\%). Poziom wykształcenia przekłada się na poziom dyscypliny w samokontroli [1].

Odnośnie zwiększania swojej wiedzy na temat cukrzycy typu 2 najwięcej badanych wskazało na rozmowę z lekarzem, pielęgniarką $(45,8 \%)$ oraz na czytanie książek, poradników, czasopism na temat cukrzycy typu 2 (22,9\%). Najwięcej badanych oceniło swój poziom wiedzy na temat cukrzycy typu 2 na ocenę "4" (41,0\%) oraz ocenę "5" (34,0\%.). Najwyżej swoją wiedzę na temat cukrzycy typu 2 ocenili badani z wyższym wykształceniem - 4,7 punktu oraz średnim - 4,0 punkty. Są to kobiety leczące się poniżej 5 lat.

Według Burkiewicza, Stasiuka, Kozłowskiego kryterium branym pod uwagę był poziom wiedzy badanych chorych na temat własnej choroby. Grupa kobiet - 60\% określiło swoją wiedzę jako dobrą. Grupa mężczyzn - 52\% uważa, że ich wiedza jest na poziomie dobrym. 
Autorzy wskazują, że im wyższe wykształcenie tym wyższa świadomość chorego na temat własnej choroby [11]. Potwierdziły to także wyniki badań własnych.

\section{Wnioski}

Na podstawie uzyskanych wyników można wyodrębnić następujące wnioski:

1. Najczęściej występującym powikłaniem w grupie badanych osób jest nadciśnienie tętnicze.

2. Znaczna większość badanych wskazuje, że edukacja chorych na cukrzycę jest ważna.

3. Najwięcej osób, jako sposób pielęgnacji stóp, zaznaczyło: mycie w letniej wodzie i delikatne osuszanie kładąc nacisk na przestrzenie między palcami.

4. Badani oceni swój poziom wiedzy o cukrzyce typu 2 na poziomie dobrym i bardzo dobrym.

\section{Zalecenia dla praktyki pielęgniarskiej.}

W oparciu o niniejszą pracę można wywnioskować, że źle kontrolowana cukrzyca prowadzi do wielonarządowych powikłań. Poprzez odpowiednie wyrównanie metaboliczne u pacjentów z cukrzycą typu 2 u których powikłania już występują można spowolnić ich progresję i zapobiec dalszemu rozwojowi

\section{Bibliografia/Bibliography}

1. Kołpa M., Grochowska A., Kubik B., Stradomska K., Styl życia i wyrównanie metaboliczne u pacjentów z cukrzycą typu 2, a ryzyko powikłań przewlekłych tej choroby, Diabetologia Praktyczna 2018; 4(3):162-170.

2. Sieradzki J.(red.) Cukrzyca. Via Medica, Gdańsk 2015. 
3. Polskie Towarzystwo Diabetologiczne, Zalecenia kliniczne dotyczące postępowania u chorych na cukrzycę 2019, Diabetologia Praktyczna 2019, tom 5 , nr 1, s. 6 .

4. Karpińska A., Łopatka P. A., Rossa S., Cwajda-Białasik J., Szewczk M. T., Znaczenie Fizjoterapii w prewencji i leczeniu cukrzycy typu 2, z uwzględnieniem zespołu stopy cukrzycowej, Pielęgniarstwo Chirurgiczne i Angiologiczne $2018 ; 2: 39-43$.

5. Jankowska-Polańska B., Uchmanowicz I., Bober A. Wpływ edukacji na jakość życia chorych z cukrzycą typu 2, Współczesne Pielęgniarstwo i Ochrona Zdrowia, 2013;2,1:7-11.

6. Szewczyk A. Pielęgniarstwo Diabetologiczne. Wydawnictwo Lekarskie PZWL, Warszawa 2014.

7. Sieradzki J.(red.) Cukrzyca. Via Medica, Gdańsk 2009.

8. Franek E. (red.) Leczenie powikłań cukrzycy i chorób z nią współistniejących. Wydawnictwo Lekarskie PZWL, Warszawa 2018.

9. Kara I., Nowicka T.M., Bryl W., Zachowania kardioprotekcyjne u chorych na cukrzycę typu 2, Forum Zaburzeń Metabolicznych, 2012;3(2):80-84.

10. Kobus G., Łagoda K., Stawicka J., Dobrzycki S., Bachurzewska-Gajewska H. Czynniki ryzyka chorób sercowo-naczyniowych u osób z cukrzycą i rozpoznaną chorobą niedokrwienną serca kierowanych na koronorografię ocena wiedzy pacjentów, Przegląd Kardiodiabetologiczny, 2010;5(3,4):151-158.

11. Burkiewicz A., Stasiuk J., Kozłowski D. Świadomość chorych i jej wpływ na jakość życia oraz współpracę z zespołem medycznym u pacjentów z cukrzycą typu II, Ann. Acad. Med. Gedan., 2017;47:39-48. 